\title{
The Islamic Shariah Principles for Investment in Stock Market
}

\author{
Md. Mahmudul Alam * \\ Senior Lecturer \\ School of Economics, Finance \& Banking (SEFB) \\ College of Business (COB) \\ Universiti Utara Malaysia (UUM) \\ Sintok, Kedah, Malaysia \\ E-mail: rony000@gmail.com

\section{Chowdhury Shahed Akbar} \\ Senior Officer \\ Southeast Bank Limited \\ Eunoos Trade Center \\ 52-53 Dilkusa C/A \\ Dhaka, Bangladesh \\ Email: akbar.chowdhury@yahoo.com \\ Shawon Muhammad Shahriar \\ Masters Student \\ Institute for Environment and Development (LESTARI) \\ National University of Malaysia (UKM) \\ Bangi, Selangor, Malaysia \\ E-mail: shawon.shahriar@gmail.com \\ Mohammad Monzur-E-Elahi \\ Associate Professor \\ Department of Islamic Studies \\ National University \\ Gazipur, Bangladesh \\ E-mail: drmanzurelahi@gmail.com \\ * Corresponding author
}

\section{Citation Reference:}

Alam, M.M., Akbar, C.S., Shahriar, S.M., and Elahi, M.M. 2017. The Islamic Shariah Principles for Investment in Stock Market, Qualitative Research in Financial Markets, 9(2): 132-146. http://www.emeraldinsight.com/doi/full/10.1108/QRFM-09-2016-0029

This is a pre-publication copy.

The published article is copyrighted by the publisher of the journal. 


\title{
The Islamic Shariah Principles for Investment in Stock Market
}

\begin{abstract}
Purpose: Due to chronic financial crises experienced during last several decades repeatedly and a failure to protect investors' rights as a result, the world is looking for an alternative form of stock market for quite some time so that interests of all relevant stakeholders can be safeguarded. At the same time, from the perspectives of devout Muslims, the current form of stock market restricts a Muslim to make investments in the market due to unsatisfying several provisions from the Islamic law, known as shariah. This study provides the criteria under which conditions the Islamic shariah permits making investments in the stock market. Hand in hand with that primary discussion, it has been eluded briefly why the Islamic shariah principles offer a better alternative against conventional practices of the stock market.

Design/methodology/approach: This is a descriptive study based on the literature review.

Findings: This study explores the basic Islamic principles of investment in stock market by revisiting the norms laid down by shariah and current global practices of Islamic stock market and indexes.

Originality/value: This study will work as a guideline for investors and market authorities to understand the original shariah rulings and the benchmark rulings for investment or establishing full-fledged Islamic stock markets, indexes, and mutual funds.
\end{abstract}

Key Words: Shariah, Capital market, Share market, Islamic stock exchange, Islamic banking, Zakat on share investment

JEL Classification: G11; P1; P47; P5

\section{INTRODUCTION}

It is considered that the concept of stock market was first introduced in France in the thirteenth century. The Islamic concept of mudrabah ${ }^{1}$, which in some way resembles with the modern stock market concept, on the other hand, can be dated back to the age of Prophet Muhammad (PBUH) in the sixth century (Al-Barwari, 2002; cited by Osmani \& Abdullah, 2009). Researchers also traced the origin of stocks to medieval Muslim traders (Robertson, 1933).

Though Muslims are considered as the pioneer of profit and loss sharing investments in businesses through contractual agreements, which predate the concept of stock markets, the current form of stock market restricts the devout among them from seeking economic bounties from it due to unsatisfying several provisions from the Islamic law or shariah. As a consequence, in spite of religious encouragement for Muslims to seek economic opportunities, they cannot engage wholeheartedly in the trading of conventional stock

\footnotetext{
${ }^{1}$ Mudarabah is a contract of profit and loss sharing in which one party provides the capital while the other party brings work or effort. The profit is shared according to predetermined mutually agreed upon ratio. Investing in company shares is permitted in Islam in a sense that it is like partnership business or mudarabah contracts which is permitted in Islam. The Islamic jurists agreed upon the permissibility of partnership business and mudarabah contracts (Al-Kasani, 1983). Investment in the stock market does not confer any assured benefits on the holder. In fact, the shareholder could even stand to lose his entire capital in the event the company in which he has invested suffers massive losses. Therefore, stock markets represent an important investment alternative that is close to the Islamic profit-and-loss-sharing investment ideal (Khatkhatay \& Nisar, 2007).
} 
markets. ${ }^{2}$ Moreover, stock markets that follow the Islamic principles are still in early stages of development, as observed by Naughton \& Tahir (1988). Tag El-Din (2002) further mentioned that most of the stock exchanges in Muslim countries are basically western-style markets which tolerate many practices that do not comply with Islamic principles. Hearn et al. (2010) mentioned that due to limited focus on the Islamic finance, there are limited literatures available on the roles and principles of Islamically compliant stock markets. Moreover, only a handful of stock markets across the globe -- such as Khartoum Stock Exchange (KSE) in Sudan, Kuala Lumpur Stock Exchange (KLSE) in Malaysia and Tehran Stock Exchange (TSE) in Iran, for example -- accommodate for the Islamic Laws of trading in the stock market.

The conventional stock markets under the capitalistic system failed to protect the interests of ordinary investors time and again due to repeated stock market crashes across the globe, resulting chronic financial crises and economic depressions. The conventional theory of Efficient Market Hypothesis (EMH) indicates that no one can get abnormal profits from the market by using any type of historical, private or public information, but many studies have shown that the market efficiency theory does not hold for many markets (Niederhoffer \& Osborne, 1966; Lo \& MacKinlay, 1988; Claessens et al., 1995; Islam \& Khaled, 2005; Alam et al., 2007; Alam \& Uddin, 2009; Uddin \& Alam, 2010; Alam, et al., 2011). Therefore, investors and market regulatory bodies are looking for an alternative form of capital market where investors' rights and interests will be best protected.

As the world has been able to observe the advantages and benefits of the Islamic principles, value based Islamic banking system in particular, at the time of recent financial crisis of 2008, the same principles and value based system now can be suggested as a good alternative of the conventional capital market system (Kuran, 1986; El-Gari, 1993; The Brussels Journal, 2009; Islamic Finance Expert, 2010; Molla \& Alam, 2013). Based on limited experiences, this study attempts to document the guidelines under which conditions the Islamic shariah permit devout Muslims in trading in the stock market. Non-Muslims can also take advantage of this value-based investment and trading guidelines in their favour. This study will be beneficial for the regulatory authorities, investors, academicians, and researchers to establish Islamic value-based stock markets and to conduct shariah-compliant halal businesses.

\section{CONDITIONS FOR SHARIAH PERMISSIBILITY OF SHARES}

The scopes of the Islamic law permeates all areas of the life of a human being ${ }^{3}$, which includes economics, finance, law, politics, government and its integral component parts ${ }^{4}$, and

2 - "O you who have believed, eat from the good things which We have provided for you and be grateful to Allah if it is [indeed] Him that you worship." [Al Quran 2:172]

- "And [We] made the day for livelihood." [Al Quran 78:11]

- "And We have certainly established you upon the earth and made for you therein ways of livelihood. Little are you grateful." [Al Quran 7:10]

3 - "Say, 'Indeed, my prayer, my rites of sacrifice, my living and my dying are for Allah, Lord of the worlds."” [Al Quran 6:162]

- "O you who have believed, obey Allah and obey the Messenger and those in authority among you. And if you disagree over anything, refer it to Allah and the Messenger, if you should believe in Allah and the Last Day. That is the best [way] and best in result." [Al Quran 4:59]

- "But no, by your Lord, they will not [truly] believe until they make you, [O Muhammad], judge concerning that over which they dispute among themselves and then find within themselves no discomfort from what you have judged and submit in [full, willing] submission." [Al Quran 4:65] 
social, ethical and religious aspects including values and social justice (Asutay, 2007; Iqbal, 1997). Since Islam dictates every single aspect of public and private interests for a believer, the guidelines about stock markets have already been in place in principle by the shariah. ${ }^{5}$ Like other areas of the shariah, it is the task of qualified jurists to extrapolate these principles, derive relevant rulings based on them, and apply them to market specific scenarios.

Al-Kasani (1983) and Zaman (1986) pointed out that the jurists have agreed upon the partnership business and mudarabah contracts which were widely practiced during the preIslamic era and also by many companions of the Prophet Muhammed (S). Al-khaiyyat (1989) further emphasized the issue and mentioned that there is no prohibition in the shariah in forming the stock company or a partnership company or selling that share to anybody. According to Al-Khaiyyat (1989), Fahd (2007) and Osmani \& Abdullah (2009), stock markets are perfectly legal in the shariah and there is no prohibition in Islam for the establishment of capital markets. Recently, Khatkhatay \& Nisar (2007) again pointed out that investment in stock markets - which conveniently opened the main investment avenue to ordinary Muslims - is close to Islamic profit and loss sharing paradigm..

Although making investments in the stock market is allowed in Islam in principle, the shariah sets out certain rules and regulations for it which differentiates an Islamically compliant stock market from a conventional stock market. These guidelines are summarized below.

\section{Characteristics of the Company}

Share or stock means ownership, and a shareholder or a stockholder means an owner of the company. The long term investors as well as the sponsors or founders are the long term shareholders who are mostly responsible for the characteristics of the company through influencing the operations, nature of the business and strategic decisions of the company. However, the short term investors, who are not investor in nature but frequently trade in the secondary market to gain short term price change, have very little influence on the operations, nature of the business and strategic decisions of the company. Therefore, the long term investors are fully responsible for the company's overall shariah provisions while the short term investors only need to look at the following characteristics of the company to avoid any violation of the shariah principles.

\section{Nature of the Business of the Company}

Shariah provides few guidelines about the nature of the company which focuses mostly on the religious value and social wellbeing. ${ }^{6}$ At the starting point, the main business of the company must be accepted (halal) according to Islamic principles. ${ }^{7}$ There are some

\footnotetext{
4 "Indeed, Allah orders justice and good conduct and giving to relatives and forbids immorality and bad conduct and oppression. He admonishes you that perhaps you will be reminded." [Al Quran 16:90]

5 "You are the best nation produced [as an example] for mankind. You enjoin what is right and forbid what is wrong and believe in Allah." [Al Quran 3:110]

6 - "And cooperate in righteousness and piety, but do not cooperate in sin and aggression. And fear Allah; indeed, Allah is severe in penalty." [Al Quran 5:2]

- "And do not consume one another's wealth unjustly or send it [in bribery] to the rulers in order that [they might aid] you [to] consume a portion of the wealth of the people in sin, while you know [it is unlawful]." [Al Quran 2:188]

${ }^{7}$ Narrated Tarif Abi Tamima: I saw Safwan and Jundab and Safwan's companions when Jundab was advising. They said, "Did you hear something from Allah's Apostle?" Jundab said, "I heard him saying, 'Whoever does a
} 
companies which are involved in completely unacceptable (haram) activities, such as the company's manufacturing, selling or offering of liquors, haram meat like pork, or involved in immoral services like gambling, discos, prostitution, night club, pornography, pubs etc. Shariah does not permit any Muslims to invest into these companies or the companies where the core income is based on these activities. ${ }^{8}$

Secondly, Islam strictly prohibits any kind of riba (usury and interest). The divine authority (Allah) mentioned that trade is permitted, but riba is forbidden. ${ }^{9}$ Along with this prohibition, the final prophet Muhammad (PBUH) cursed the practice of receiving and giving interest. $^{10}$

According to Islamic principles, it is not permissible to acquire the stocks of the companies which are directly or indirectly attributed to riba or interest. Companies that provide financial services on interest, such as interest based banks, insurance companies, finance and leasing companies, etc. also fall under this category of prohibition.

In reality, the world is so complex and interlinked that in many cases, for local or international businesses, it is not possible to avoid the transaction from any interest based banking or any sort of involvement with interest. Further, in case of mixed kind of businesses, where multisectoral companies are involved in both halal and haram activities, the Islamic jurists from four major school of Islamic thoughts - Hanafi, Maliki, Shafi and Hanbali - agreed on the permissibility of investing in such companies under specific conditions (Khatkhatay \& Nisar, 2007; Jamal et al., 2010).

According to Justice Mufti Muhammad Taqi Usmani, if the main business is halal, but the company borrows money on interest or places its money into interest-bearing

good deed in order to show off, Allah will expose his intentions on the Day of Resurrection (before the people), and whoever puts the people into difficulties, Allah will put him into difficulties on the Day of Resurrection."' The people said (to Jundab), "Advise us." He said, "The first thing of the human body to purify is the abdomen, so he who can eat nothing but good food (Halal and earned lawfully) should do so, and he who does as much as he can that nothing intervene between him and Paradise by not shedding even a handful of blood, (i.e. murdering) should do so." [Sahih al-Bukhari, Book 9, Volume 89 (Judgments), Hadith 266]

8 "And you see many of them hastening into sin and aggression and the devouring of [what is] unlawful. How wretched is what they have been doing." [Al Quran 5:62]

9 - "And whatever you give for interest to increase within the wealth of people will not increase with Allah. But what you give in Zakat, desiring the countenance of Allah - those are the multipliers." [Al Quran 30:39]

- "Those who consume interest cannot stand [on the Day of Resurrection] except as one stands who is being beaten by Satan into insanity. That is because they say, 'Trade is [just] like interest.' But Allah has permitted trade and has forbidden interest. So whoever has received an admonition from his Lord and desists may have what is past, and his affair rests with Allah. But whoever returns to [dealing in interest or usury] - those are the companions of the Fire; they will abide eternally therein. Allah destroys interest and gives increase for charities. And Allah does not like every sinning disbeliever. Indeed, those who believe and do righteous deeds and establish prayer and give Zakat will have their reward with their Lord, and there will be no fear concerning them, nor will they grieve. O you who have believed, fear Allah and give up what remains [due to you] of interest, if you should be believers. And if you do not, then be informed of a war [against you] from Allah and His Messenger. But if you repent, you may have your principal - [thus] you do no wrong, nor are you wronged. And if someone is in hardship, then [let there be] postponement until [a time of] ease. But if you give [from your right as] charity, then it is better for you, if you only knew. And fear a Day when you will be returned to Allah. Then every soul will be compensated for what it earned, and they will not be treated unjustly." [Al Quran 2:275281]

${ }^{10}$ Narrated Abu Juhaifa: The Prophet cursed the lady who practices tattooing and the one who gets herself tattooed, and one who eats (takes) Riba (usury) and the one who gives it. And he prohibited taking the price of a dog, and the money earned by prostitution, and cursed the makers of pictures. [Sahih al-Bukhari, Book 7, Volume 63 (Divorce), Hadith 259] 
accounts, shareholders should raise their voice against this practice in the annual general meeting of the company (Usmani, 2010). When Muslim shareholders receive dividend, they must ascertain the proportion of dividend coming from interest-bearing activities and give them to charity. He also mentioned that shariah scholars have permitted to invest in stocks of companies whose income from interest-related activities is less than $5 \%$ of the company's total income. Butt (2014) elaborates that the income of the company from non-shariah compliant investment, which includes interest, should not exceed 5\% of its gross revenue.

The OIC (Organisation of Islamic Cooperation) Fiqh Academy, which includes fiqh Scholars from 53 majority Muslim countries across the world, made several resolutions and recommendations for purchasing stocks (Ahmad, Ripain, \& Noor, 2014), such as:

- Stocks of companies whose products are not permitted in shariah are prohibited to own, purchase, sell etc. Examples: interest-based banks and insurance companies, entertainment business, etc.

- Stocks of companies that abide by the rules of shariah, such as Islamic banks and Islamic insurance companies are permissible.

- Stocks of companies whose products are permissible but the company indulges in non-allowed transactions - such as getting interest based financing, depositing in banks for interest, making contracts that include prohibited conditions, e.g., selling gold and/or silver and/or currencies in other than spot, or giving donations or selling arms to aggressors - and companies that produce permissible products but also produce non permissible products as a minor line of production are not permissible in principle.

The Financial Services Authority of Indonesia (Kasi \& Muhammad, 2016) categorizes stocks as shariah compliant if the issuer company declares that its business activities as well as its business management are conducted based on the shariah principles and it is not involved in any of the following businesses:

- Gambling

- Trading with non-deliverance of goods or service

- Trading with counterfeit offering/demand

- Conventional banks

- Conventional leasing companies

- Trading of risk that contain uncertainty (gharar) and/or gambling (maisir), e.g conventional insurance

- Producing, distributing, trading and/or providing products or services that are forbidden because of its contents; products or services that are forbidden not because of its' contents but because they are stated forbidden by the National shariah BoardMUI; and/or products or services that can degrade one's morals and are purposeless

- Doing transactions that contain bribe substance

According to Shariah Advisory Council (SAC) of the Securities Commission Malaysia, mixed types of companies are permitted by shariah on the following conditions:

- The core activities of companies must be halal and the haram elements must be small compared to core activities;

- Public perception or image of the companies must be good; and 
- The core activities of the companies should have important benefit to the Muslim ummah (nation) and the country, and the haram elements - including umum balwa (common plight and difficult to avoid), urf (customs and rights of the non-Muslim community) - which are accepted by Islam must be very small.

In a broader perspective, previously in 2007, SAC of Securities Commission Malaysia (2007) set several benchmarks to determine a tolerable level of permissible and nonpermissible activities such as:

a. The five-percent (5\%) benchmark: This benchmark is applied to measure the level of mixed contributions from the activities that are clearly prohibited such as interestbased companies (like conventional banks, insurances, financing and leasing companies etc.), gambling, liquor, pork, pornography, etc.

b. The ten-percent (10\%) benchmark: This benchmark is applied to measure the level of mixed contributions from the activities that involve the element of umum balwa (prohibited elements affecting most people and difficult to avoid). For example, interest income from fixed deposit in conventional banks, revenue generated from tobacco-related activities as a tiny part of an overall shariah-compliant business.

c. The twenty-percent (20\%) benchmark: This benchmark is applied to assess the level of contribution from mixed rental payment from shariah non-compliant activities, such as rental payment from the premise that involved in gambling, sale of liquor etc.

d. The twenty-five percent (25\%) benchmark: This benchmark is applied to assess the level of mixed contribution from the activities that are generally permissible according to shariah and have an element of maslahah (public interest) to the public, but there are other elements that may affect the shariah status of these activities. For example, hotel and resort operations, share trading, stock brokerage houses, aeroplane companies etc., as these activities may involve other relevant activities that are deemed non-permissible by the shariah.

Furthermore, the SAC of Securities Commission Malaysia (2012) revised its benchmark criteria in 2012 and reduced the business activity benchmarks from four benchmarks to only two benchmarks:

a. The five percent (5\%) benchmark: The contributions from these activities to the group turnover and profit before taxation should not exceed 5\% - conventional banking, conventional insurance, gambling, liquor and liquor-related activities, pork and porkrelated activities, non-halal food and beverages, shariah non-compliant entertainment, interest income from conventional accounts and instruments including dividends from investment in shariah non-compliant instruments and interest income awarded arising from a judgment by a court or arbitrator, tobacco and tobacco-related activities, and other activities deemed non-compliant according to Shariah.

b. The twenty percent (20\%) benchmark: The contributions from these activities to the group turnover and profit before taxation should not exceed 20\%: hotel and resort operations, share trading, stock broking business, rental received from shariah noncompliant activities, and other activities deemed non-compliant according to shariah.

\section{Nature of the Assets of the Company}

Shariah also provides some guidelines on the nature of the assets of the company focusing on safeguarding the investors' interests and rights. First of all, it does not permit to invest in a 
company which has got only liquid assets. If the company does not have any non-liquid asset, it would only be permissible to trade at the par-value of the shares, because in this case the shares represent similar to cash money. Thus, trading above or below the par-value would be considered as riba under Islamic principles (Usmani, 2010). In reality, almost all of the companies have both liquid and non-liquid assets. In that case, the jurists have different views towards the ratio of liquid assets to total assets. The Shafi and Hanbali schools of thought have set this minimum at 51\%, while scholars from Hanafi school of thought have opined that the ratio must not be more than 33\% (Jakhura, 2010). Meezan Islamic Fund Criteria in Pakistan has set out the ratio of net illiquid assets of the investee company as a percentage of the total asset should be up to $10 \%$ (Khatkhatay \& Nisar, 2007), whereas the S\&P Islamic Index allows this ratio up to $49 \%$, FTSE Islamic Index allows up to $45 \%$, and the Dow Jones Islamic Market Index (DJIMI) allows up to 33\%.

Moreover, Hanafi scholars also added two mandatory conditions. Firstly, the nonliquid part of the combination should not be in an ignorable quantity. Secondly, the price of the mixture of both liquid and non-liquid assets should be more than the price of the liquid amount contained therein. Usmani (2010) provided a good theoretical example. A share for $\$ 75$ cash and some fixed assets holding company's price must be above $\$ 75$. If the price is set at $\$ 70$, it is considered as riba due to the lesser price than liquid assets. If the price is set at $\$ 75$, it is also not permissible due to insignificance or zero value for fixed assets. As such, any value above $\$ 75$ is valid due to having a value for the fixed assets. In the real world, it is very difficult to imagine a situation where a price of the share goes lower than its liquid assets.

Besides them, because of the rapid spread of the internet since the late 1990s, a new form of business has emerged where many companies have been offering high-value services and software-based solutions without the need of possessing any significant physical inventory and assets. Although these companies are not in the business of manufacturing, trading, retailing or service in the conventional sense, they impact the lives of billions of people all over the world. Instead of acquiring physical assets, these knowledge-based companies rely mostly on research, innovation and patents. Although applying the conventional shariah practices related to the ratio of liquid and illiquid assets is not practical for these companies, the services they provide are real, valuable and in many cases necessary. The emergence of this innovative form of business necessitates conducting fresh research on this issue and promulgating the necessary resolutions from respectable fiqh councils.

\section{Debt to Equity ratio}

Shariah principles do not allow interest bearing debt. However, based on Islamic principles, shariah scholars have allowed investment into a company if its debt-financing is not more than 33\% (Butt, 2014). The Dow Jones Islamic Market Index and FTSE Islamic Index exclude the companies in which debt to asset ratio is greater than or equal to 33\%. Shariah Advisory Council (SAC) of Securities \& Exchange Commission in Malaysia also follows this $33 \%$ standard. Meezan Islamic Fund Criteria in Pakistan, on the other hand, allows up to 45\% debt to asset ratio (Khatkhatay \& Nisar, 2007).

\section{Characteristics of the Investor}

\section{Nature of the Ownership}

Normally, stocks can be divided into two categories, namely: common stock and preferred stock. Common stock holders have voting rights and are considered as the real owners of the 
company. They only have a residual claim (whatever is left) on income and asset in the case of company's liquidation. On the other hand, preferred shareholders do not have the right to vote, and they are not considered as actual partners of the company. Preferred stock has a priority claim over common shareholders to a company's assets and earnings and must be paid before common stockholders. Dividends of preferred stocks are generally greater than those of common stocks and are paid at regular intervals. Since preferred shareholders do not have the right to vote, and they are not considered as actual partners of the company, therefore, the extra money they get is like riba as they take it without sharing the risk of profit and loss (Zaky, 1992).

Shariah allows only common stocks to be traded. There seems to be a consensus of opinion among contemporary jurists on the permissibility of exchanging common stocks through buying and selling transactions (Ahmad, Ripain, \& Noor, 2014). Selling a common share is like selling a portion of the share of the company; and it is considered as an individual's property, where the owner has the right to sell or lend as long as it does not cause harm to other shareholders (Osmani \& Abdullah, 2009). Islamic Fiqh Academy declared that investing in ordinary shares is permissible if the main business of the company is in compliance with shariah ruling (Ahmad, Ripain, \& Noor, 2014).

\section{Nature of the Intention}

In stock markets, speculation exists by nature and one might argue that speculation resembles with gambling and therefore investment in shares is not permissible by shariah. The argument here is that in stock market, the buying or selling is done with the intention of making a profit anticipating that price will change and gain will come from natural or artificial price differences, speculators are therefore believed to behave with unusual patterns of the markets within the random walks of stock price movements through the adoption of different 'gambling' positions (Tag el-Din \& Hassan, 2007).

In shariah, qimar or gambling is strictly prohibited. ${ }^{11}$ There are two types of gambling - one way is just trying to invest with the concept of being lucky based on excessive risk, just like spending money in the general case of gambling (Chapra, 1985), and another way is trying to get extra or abnormal profit through pulling up the price by any type of manipulation such as forming a syndicate, spreading rumours, etc. ${ }^{12}$ This concept also covers unusual, illogical, manipulated and unethical speculation in the stock market which refers to trading in stock market purely for short-term gains, resulting uncertainty in the market and sure losses or longer term positioning of the share for others.

The issue of speculation has been addressed by shariah scholars and they have provided their views on the issue. El-Ashkar (1995) pointed out that investors in stock market buy securities on the hope that their prices will go up in the future and they will be able to realize capital gains. Even those who do not sell when prices go up, they do it on the hope that the prices will move up even further. If they had known that prices would fall they would

\footnotetext{
11 "O you who have believed, indeed, intoxicants, gambling, [sacrificing on] stone alters [to other than Allah], and divining arrows are but defilement from the work of Satan, so avoid it that you may be successful." [Al Quran 5:90]

${ }^{12}$ Ibn 'Abbas said: Allah's Apostle said, "Do not go to meet the caravans on the way (for buying their goods without letting them know the market price); a town dweller should not sell the goods of a desert dweller on behalf of the latter." (The narrator) asked Ibn "Abbas, "What does he mean by not selling the goods of a desert dweller by a town dweller?" He said, "He should not become his broker." [Sahih al-Bukhari, Book 3, Volume 34 (Sales and Trade), Hadith 367]
} 
have behaved differently. This is behaviour quite legitimate. The objective of these investors is to maximize their holdings even if not to instantly realize capital gains. The difference between speculators and other investors is that while the former buy and sell in a very short time, the latter take longer to do so. He also concluded that an Islamically compliant stock market will not be totally speculation-free, because a reasonable degree of speculation would be required, and indeed needed, if the market is to be active and operative.

The Shariah Advisory Council (SAC) at its tenth meeting on 16-17 October 1997, and at its eleventh meeting on 26 November 1997, on discussing the issue of crude palm oil futures, resolved that speculation is permissible under Islamic jurisprudence. Several arguments have been used to support the permissibility of the speculation. According to SAC, speculation and gambling appear to be similar in practice. As such, we do hear, for example, the exhortation not to treat the share market as a casino. This perception arises because speculators enter the market depending solely on luck, similar to gambling. But the share market is not a place for gambling. It is a place that allows shareholders to dispose ownership of shares to other investors in order to gain liquidity. Whether it is gambling or not depends on the conduct of the investors who enter and leave the market, and their motives.

Therefore, it can be concluded that under the shariah provision, the baseline of speculation is founded on the intention or behaviour of the investors. ${ }^{13}$ The decisions must not be based on uncertainty and generating excessive risk, but based on the fundamental analysis and intention to get normal profit from the market.

\section{Characteristics of the Transaction}

\section{Nature of the Transaction}

The pattern of transaction and its form differs among markets as well as among Islamic jurists. There are several trading practices available in the stock market, such as margin trading, derivatives- options and futures, short-selling, etc. The legality of these issues vary from market to market, conventional laws and Islamic scholars. Many markets prohibit them because of their involvement in market manipulation and speculations. Islamic scholars prohibit them because of their involvement in interest and speculations.

According to Osmani and Abdullah (2009), many Islamic jurists disagree on the validity of forwards, future and options as the sold commodity and payment of the price are made in a future date resulting in the elements of gharar (uncertainty) and gambling. ${ }^{14}$ The shariah forbids gharar (selling something that is not owned or that cannot be described in accurate detail in terms of type, size, and amount) (Hassan \& Girad, 2010).

Al-Barwari (2002) (cited by Osmani \& Abdullah, 2009) pointed out that the council of the Islamic Fiqh Academy of Mecca decided that forward contracts with all of its categories which are prevalent in the stock market are invalid due to selling things that a

\footnotetext{
13 'Umar bin al-Khattab narrated: I heard Allah's Apostle saying, "The reward of deeds depends upon the intentions and every person will get the reward according to what he has intended." [Sahih al-Bukhari, Book 1, Volume 1 (Revelation), Hadith 1]

${ }^{14}$ Abu Huraira (Allah be pleased with him) reported that Allah's Messenger (may peace be upon him) forbade a transaction determined by throwing stones, and the type which involves some uncertainty. [Sahih Muslim, Book 10 (The Book of Transactions), Hadith 3614]
} 
person does not own. ${ }^{15}$ Similarly, the short-selling violates the shariah principle for the same reason. Chapra (1985) strongly opposed the existence of short-selling in an Islamic market, arguing that such sales are speculative involving riba and gharar in the whole transaction and fails to perform any useful economic function. Naughton \& Naughton (2000) observed that by prohibiting short sales, masalahah (public interest) is best served..

However, a handful of Islamic jurists have permitted this type of contracts based on a reported tradition of prophet Muhammad (PBUH) where he himself got involved in a forward contract, as prophet Muhammad (PBUH) purchased a thin weak camel from Jabir with a price of one gold coin, which he paid later and Jabir also handed over the camel at a later date. $^{16}$ The Shariah Advisory Council (SAC) of the Securities Commission Malaysia legalized this by regulated short-selling (RSS) with the inclusion of securities borrowing and lending (SBL) principles in Malaysia. According to them, under RSS, fulfillment of delivery, settlement of contracts and payment of financial obligations are always guaranteed, monitored and regulated, which reduces the elements of gharar, resulting in short-selling to be shariah-compliant. Nevertheless, Dusuki \& Abozaid (2008) analyzed this permissibility further and argued that SAC should reconsider its position as the issue of benefiting from loan, which refers to riba, is still undefended. It is obligatory for Muslim to seek halal (legitimate) earnings. Osmani \& Abdullah (2009). on the other hand, permitted these type of contacts under the condition that forward, futures and options are only valid when both parties agree on the stipulated duration and price, with no uncertainty in the transaction.

\section{Nature of the Zakat (compulsory tax) Provision}

There is compulsory gain tax in many of the conventional stock markets. In Islam, under shariah principles, there is no mandatory gain tax but there is annual tax, called zakat, on selected assets if they go beyond a certain level. The zakat (compulsory tax) on stocks is obligatory upon the owners of the shares. The zakat may be paid by the company on behalf of the Muslim shareholders or by the shareholders themselves. When zakat is paid at the corporate level, the company is supposed to receive corporate tax benefits for calculating low return alongside with providing charity or CSR (corporate social responsibility). The

\footnotetext{
15 Narrated Hakim ibn Hizam: Hakim asked (the Prophet): Apostle of Allah, a man comes to me and wants me to sell him something which is not in my possession. Should I buy it for him from the market? He replied: Do not sell what you do not possess. [Sunan Abu Dawud, Book 23 (The Book of Wages), Hadith 3496]

16 Jabir b. 'Abdullah (Allah be pleased with them) reported: I went on an expedition with Allah's Messenger (may peace be upon him). He overtook me and I was on a water-carrying camel who had grown tired and did not walk (trot). He (the Holy Prophet) said to me: What is the matter with your camel? I said: It is sick. He (the Holy Prophet) stepped behind and drove it and prayed for it, and then it always moved ahead of other camels. He (then) said: How do you find your camel? I said: It is, by the grace of your prayer, all right. He said: Would you sell this (camel) to me? I felt shy (to say him," No" ) as we had no other camel for carrying water, but (later on) I said: Yes, and to I sold it to him on the condition that (I would be permitted) to ride it until I reached Madina. I said to him: Allah's Messenger, I am newly married, so I asked his permission (to go ahead of the caravan). He permitted me, and I reached Medina well in advance of other people, until I reached my destination. There my maternal uncle met me and asked me about the camel, and I told him what I had done with regard to it. He reproved me in this connection. He (Jabir) said: When I asked his permission (to go ahead of the caravan) Allah's Messenger (may peace be upon him) inquired of me whether I had married a virgin or a non-virgin. I said to him: I have married a non-virgin. He said: Why did you not marry a virgin who would have played with you and you would have played with her? I said to him: Allah's Messenger, my father died (or he fell as a martyr), and I have small sisters to (look after), so I did not like the idea that I should marry a woman who is like them and thus be not able to teach them manners and look after them properly. So I have married a non-virgin so that she should be able to look after them and teach them manners, When Allah's Messenger (may peace be upon him) came to Medina, I went to him in the morning with the camel. He paid me its price and returned that (the camel) to me. [Sahih Muslim, Book 10 (The Book of Transactions), Hadith 3888]
} 
company pays zakat if that is stated in the company's constitution, or by law, or by management decision, or based on shareholders' authorizations to pay on their behalf. If zakat is not paid by the company, Muslim shareholders needs to pay it individually, which will cause a lower rate of return for the investors. Moreover, if a Muslim investor adheres to all shariah principles for investing in the stock market but fails to pay the zakat due on these shares, he is considered morally sinful in Islam. The entire exercise of following shariah principles meticulously becomes a paradox if the investors ignore the payment of zakat.

There are two ways to calculate zakat at individual level, depending on the nature of the investors. If the shareholder is a short term investor, , who has the intention for price gain and is ready to sell the share anytime when price increases, then zakat will be calculated on the full market value of the share every year. If the shareholder is a long term investor, who has no intention to take any short price gain but invests for dividend gain, then zakat will be calculated only on the dividend amount every year, and onetime zakat on the full selling price at the time of selling the share (Bradford, 2015). Moreover, the calculation of zakat for long term investors also depends on the nature of the company, such as:

- For service based companies that do not engage in any kind of trade, such as hotels, transportation companies, etc., no zakat is due on assets but on the cash or account receivable that completed one full lunar year and the profits of these shares, because the value of these shares is based on equipment, tools, buildings, furnishings and so on, which are exempted from the calculation of zakat;

- For companies which engage only in trade, such as distributors, importers, exporters, international traders, etc., and for the companies which engage both in manufacturing and trade, such as petroleum companies, textile companies, metal companies, chemical companies, etc. that extract or buy raw materials, and trade them with some changes, zakat must be calculated on the cash or account receivable that completed one full lunar year, the inventory (for selling purpose) of these companies, and the profit of the share; and

- For agriculture and livestock companies, zakat needs to be calculated on the crops, fruits and livestock beyond a certain level of productions, such as 10\% if the crops are irrigated naturally and 5\% if they are irrigated artificially when the shares reach a certain level.

The annual zakat rate is $2.5 \%$ generally for the lunar calendar year (Arabic/ Hijri calendar) or $2.58 \%$ for solar calendar year (any normal calendar such as Gregorian calendar). The zakat is mandatory only in the case of when total share value of the shareholder is equal to or above the price of 595 grams of silver or 85 grams of gold, and according to many jurists it should be in continuous possession for a period of one lunar year. The Hanafi jurists do not consider continuous possession as a condition, rather if the stipulated amount is present both in the beginning date of the calculation cycle and on the same date the following year then zakat needs to be paid on it regardless of what happened in between these dates. The calculated value of the zakat can be paid from personal cash fund if not possible to pay by selling the share at the end of the year.

Another option is to keep the zakat due till the time of finally selling the share. In this method, zakat is calculated on market value for each year and all due amounts should be disbursed together from the final selling price. A hypothetical example for the trading case: holding a share of which the current market price is $\$ 100$. Thus, (year 1) the due zakat is: $2.5 \%$ of $\$ 100=\$ 2.5$. The following year (year 2 ), suppose the current market price is $\$ 200$. 
As such, (year 2) the due zakat is: $2.5 \%$ of $\$ 200=\$ 5$. Now, total due for two years is $\$ 7.5$. If the share is sold at the end of the 2nd year, total zakat of $\$ 7.5$ will be paid from the selling amount. If any dividend is received within the period, zakat also needs to be calculated on that gained amount.

The zakat amount can be distributed by the shareholders individually or by the government to eight categories of people who are eligible to receive zakat - poor, needy, people employed to collect or administer the zakat funds, non-Muslims or Muslim who need to be attracted regarding Islam. ${ }^{17}$ In addition, one can present the money to free slaves and captives, pay off the debt on behalf of an unable person, and to those who are fighting for the sake of Allah.

\section{CONCLUSIONS}

The conventional efficient market theory focuses on the rights of the investors and works as safeguard from unusual financial crisis, even from any extraordinary return by any group, which is not yet ensured since inception under the current capitalistic form of capital market system. The outcomes of chronic financial crisis suggested that market should be run by a system which will ensure efficiency, justice, fairness, accountability, fair distribution of benefits among investors, good governance, and ethical characteristics of the investors. The western given format of the capital market including its efficiency theory failed to ensure the practical safeguard for tiny and less efficient investors.

On the other hand, at the time of recent financial crisis, the world observed the superiority of value based principles of Islamic shariah system for the banking sector. Therefore, to protect the investors' rights, stock market under the same value based system can be suggested as a good alternative of the conventional stock market system. This article focuses on these rules and regulations of Islamic shariah for the stock market that are ignored by the conventional market efficiency theory. While exploring the basic Islamic principles of investment in stock market, the paper revisits the norms laid down by shariah as well as current practices of Islamic stock market and indexes around the world. Therefore, it will help the investors to setup their own standard of benchmark for investment in stock market, and the market authorities will get a guideline to establish Islamic index, mutual funds, and a full-fledged Islamic stock market.

\section{REFERENCES}

Ahmad, N.W., Ripain, N., Noor, N.H.N.M. 2014. Investment in Stock Market: A Review on Islamic Perspectives, E-proceedings of the Conference on Management and Muamalah (CoMM 2014), 26-27 May, Kolej Universiti Islam Antarabangsa Selangor (KUIS), Kajang, Malaysia.

Alam, M.M., \& Uddin, M.G.S. 2009. Relationship between Interest Rate and Stock Price: Empirical Evidence from Developed and Developing Countries, International Journal of Business and Management, 4(3), 43-51.

\footnotetext{
17 "Zakat expenditures are only for the poor and for the needy and for those employed to collect [Zakat] and for bringing hearts together [for Islam] and for freeing captives [or slaves] and for those in debt and for the cause of Allah and for the [stranded] traveler - an obligation [imposed] by Allah. And Allah is Knowing and Wise." [Al Quran 9:60]
} 
Alam, M.M., Alam, K.A., \& Uddin, M.G.S. 2007. Market Depth and Risk Return Analysis of Dhaka Stock Exchange: An Empirical Test of Market Efficiency, ASA University Review, 1(1), 93-101.

Alam, M.M., Yasmin, S., Rahman, M., \& Uddin, M.G.S. 2011. Effect of Policy Reforms on Market Efficiency: Evidence from Dhaka Stock Exchange, Economics Research International, 2011(1).

Al-Barwari, S.M. 2002. Bursat Al-Awraq Al-Maliyyah Min Manzurin Islamiy, Darul Fikr, Damascus.

Al-Kasani, A.A.B.M. 1983. Bada'i`As-Sana'T, Matba`at al- Imam: Cairo.

Al-Khaiyyat, A. A. 1989. As-Sharikat fi Daw' Al-Islam, Al-Guriyyah: Amman.

Asutay, M. 2007. Growth and Current Evolution of the Islamic Financial Industry, International Workshop on Islamic Economics: Theoretical and Practical Perspectives in a Global Context. Takushoku University, Tokyo, Japan, 21 July.

Bradford, J. 2015. Do I Have to Pay Zakat on My Stocks and Shares? Muslim Money Guide. Texas, USA. http://www.muslimmoneyguide.com/do-i-have-to-pay-zakat-on-mystocks-and-shares/ (Accessed on 19 January, 2017)

Butt, M.Z. 2014. Research Paper on Investment in Stocks and Shares. Al-Qalam Sharí'ah Scholar Panel. Bolton, UK. http://alqalam.org.uk/research-papers/investment-instocks-and-shares/ (Accessed on 19 January, 2017).

Chapra, M. U. 1985. Towards a Just Monetary System, The Islamic Foundation: Licester.

Claessens, S., Dasgupta, S. \& Glen, J. 1995. Return Behaviour in Emerging Stock Markets, The World Bank Economic Review, 9(1), 131-151.

Dusuki, A. W. \& Abozaid, A. 2008. Fiqh Issues in Short Selling as Implemented in the Islamic Capital Market in Malaysia, JKAU: Islamic Economics, 21(2), 63-78.

El-Ashkar, H.A.F. 1995. Towards an Islamic stock exchange in a transitional stage. Islamic Economic Studies, 3(1), 79-112.

El-Gari, M.A. 1993. Towards an Islamic Stock Market, Islamic Economic Studies, 1(1), pp. 1-21.

Fahd, B.A.R.A. 2007. At-Takyif Al-Fiqhi Li as-Saham fi Ash-Sharikat Al-Musahamah Wa 'Asruhu, Daru Kunuji Isbilia: Riyadh.

Hassan, M.K. and Girard, E. 2010. Faith-based Ethical Investing: The Case Of Dow Jones Islamic Indexes, Islamic Economic Studies, 17(2), 1-32.

Hearn, B.A., Strange, R.N. \& Piesse, J. 2010. The Role of the Stock Market in the Provision of Islamic Development Finance: Evidence from Sudan, SSRN, (online) http://ssrn.com/abstract=1302935 (Accessed on 19 January, 2017).

Iqbal, Zamir. 1997. Islamic Financial Systems, Finance and Development, 34(2), 42-45, (online) http://www.imf.org/external/pubs/ft/fandd/1997/06/pdf/iqbal.pdf (Accessed on 19 January, 2017).

Islam, A. \& Khaled, M. 2005. Tests Of Weak-Form Efficiency Of The Dhaka Stock Exchange, Journal Of Business Finance \& Accounting, 32(7-8), 1613-1624.

Islamic Finance Expert. 2010. Islamic Finance: Can it save Western Banks?, 30 June, (online) http://ifinanceexpert.wordpress.com/2010/06/30/islamic-finance-can-it-savewestern-banks/ (Accessed on 19 January, 2017).

Jakhura, S. \& Mangera, M.D. 2010. Share Trading, December 26, (online) http://www.albalagh.net/qa/0143.shtml (Accessed on 19 January, 2017).

Jamal , J., Hambali, N. \& Ali, H. M. 2010. Islamic Capital Market and Shariah Screening in Malaysia, presented at International Research Symposium in Service Management, Mauritius, 24-17 August. 
Kasi, U. \& Muhammad, J. 2016. Strict and Uniform Shariah Screening Methodologies in Selected Asian Countries in Comparison with the United States, Asian Journal of Finance \& Accounting, 8(1), 38-76.

Khatkhatay, M. H. \& Nisar, S. 2007. Shari'ah Complaint Equity Investments: An assessment of Current Screening Norms. Islamic Economic Studies, 15(1), 1-30.

Kuran, T. 1986. The economic system in contemporary Islamic thought: interpretation and assessment, International Journal of Middle East Studies, 18(2), 135-164.

Lo, A.W. \& Mackinlay, A.C. 1988. Stock Market Prices Do Not Follow Random Walks: Evidence from A Simple Specification Test, Review of Financial Studies, 1, 41-66.

Molla, R.I. \& Alam, M.M. 2013. A Third Sector-Led Economic Model: Scopes for Islamic Entrepreneurship, American Journal of Islamic Social Sciences, 30(1): 73-91.

Naughton, S. \& Naughton, T. 2000. Religion, Ethics and Stock Trading: The Case of an Islamic Equities Market. Journal of Business Ethics, 23, 145-159.

Naughton, T \& Tahir, M.A. 1988. Islamic Banking and Financial Development, Journal of Islamic Banking \& Finance, 5(2), 60-76.

Niederhoffer, V. \& Osborne, M.F.M. 1966. Market Making and Reversal on the Stock Exchange, Journal of the American Statistical Association, 61, 897-916.

Osmani, N.M. \& Abdullah, M. F. 2009. Towards An Islamic Stock Market: A review of Classical and Modern Literatures, International Review of Business Research Papers, 5(5), 121-130.

Robertson, H. 1933. Aspects of the Rise of Economic Individualism, Cambridge University Press: Cambridge.

Sahih al-Bukhari: The Translation of the Meanings, Dar-us-Salam Publications: Riyadh.

Sahih Muslim (Arabic-English), Adam Publishers \& Distributors: New Delhi.

Securities Commission Malaysia. 2007. Resolutions of the Securities Commission Shariah Advisory Council, Kuala Lumpur, Malaysia. (Online) https://www.sc.com.my/wpcontent/uploads/eng/html/icm/Resolutions_SAC_2ndedition.pdf (Accessed on 19 January, 2017).

Securities Commission Malaysia. 2012. Resolutions of the Shariah Advisory Council of the Securities Commission Malaysia, 2012- 2014, Kuala Lumpur, Malaysia. (Online) https://www.sc.com.my/wp-content/uploads/eng/html/icm/Resolution_SAC_20122014.pdf (Accessed on 19 January, 2017).

Sunan Abu Dawud, English Translation with Explanatory Notes, Al-Madina Publications: New Delhi.

Tag el-Din, S. and Hassan, M. K. 2007. "Islam and speculation in the stock exchange", in Kabir Hassan, M. and Lewis, M. (Eds), Handbook of Islamic Banking, Chapter 15, Edward Elgar Publishing Company, London.

Tag El-Din, S.I. 2002. Towards an Islamic Model of Stock Market, Journal of KAU Islamic Economics, 14, 3-29.

The Brussels Journal. 2009. Vatican Paper Supports Islamic Finance: France Wants Its Share of Sharia Banking, March 12. (Online) http://www.brusselsjournal.com/node/3819 (Accessed on 19 January, 2017).

The Quran (Arabic Text with Corresponding English Meaning), Dar Abul-Qasim: Jeddah, (online) http://quran.com/ (Accessed on 19 January, 2017).

Uddin, M.G.S., \& Alam, M.M. 2010. The Impacts of Interest Rate on Stock Market: Empirical Evidence from Dhaka Stock Exchange, South Asian Journal of Management Sciences, 4(1), 21-30.

Usmani, M.T. 2010. Principles of Shariah Governing Islamic Investment Funds, (online) http://www.albalagh.net/Islamic_economics/finance.shtml (Accessed on 19 January, 2017). 
Zaky, N.Z.D.Y.Z. 1992. An Islamic perspective of Stock Market-An Introduction, Dian Darulnaim Sdn. Bhd: Malaysia.

Zaman, M. R. 1986. The Operation of the Modern Financial Markets for Stocks and Bonds and its Relevance to an Islamic Economy. American Journal of Islamic Social Sciences, 3(1), 125-140. 